\title{
CONSIDERATION ON THE DEVELOPMENT OF JUDICIAL EXPERTISE PRIOR TO 1st OF DECEMBER 1918
}

\section{Elena-Ana IANCU}

\author{
E.-A. IANCU, M. LĂZĂU
}

Alexandru Ioan Cuza Police Academy, Doctoral School of Law, Bucharest, Romania Faculty of Juridical and Administrative Sciences, Agora University of Oradea, Romania *Correspondence: Elena-Ana Iancu, Agora University of Oradea, 8 Piaţa Tineretului St., Oradea, Romania

E-mail: anaelena2009@yahoo.com

\section{Marin LĂZĂU PhD Candidate}

"Alexandru Ioan Cuza" Police Academy, Doctoral School of Law, Bucharest, Romania Ministry of National Defense

E-mail: armyylaw@gmail.com

\section{ABSTRACT:}

We will approach the history of expertise, in the context of the event of $1^{\text {st }}$ December 1918, by setting forth a few considerations, with particular reference to data which appear to have this specific significance.

KEYWORDS: history, expertise, justice, $1^{\text {st }}$ of December 1918

\section{CONSIDERATIONS REGARDING THE DEVELOPMENT OF JUDICIAL EXPERTISE WORLDWIDE}

Throughout the history of evidentiary systems, the orders to perform expertise and the performance thereof have evolved together and, depending on the historical stages covered, the appearance, maintenance or disappearance of some of its forms followed a certain dynamics.

Some attempts to introduce scientific data in the activity of investigation of criminal acts have been known since ancient times.

One of the oldest methods of document investigation ever mentioned was the comparison of written documents. With regard to this method, a law dating back to the times of Roman Emperor Constantine, issued around year 300 A.D., contained a special section on forgery, in which, among the methods listed for the investigation of documents, there is data on the examination of documents through comparative methods, whereas, in the medieval period, all authors, when given the opportunity, write about how the signature of King Charles IX of France was forged. However, these methods were used in an isolated manner, without being enshrined as stand-alone rules ${ }^{1}$.

In China, the first forensic medicine treatise was written in year 1248, entitled the $\mathrm{Hei}$ Yuan $L u$ Treatise, which contains memorable instructions regarding the investigation of corpses, the variety and complexity of wounds individualized depending on the object used in order to commit the deed. Also, a difference was made between death by drowning and death due to other causes.

\footnotetext{
${ }^{1}$ Mihuleac Emil, Expertiza judiciară (Judicial Expertise), Editura Ştiinţifică (Scientific Publishing House), Bucharest, 1971, p. 93 and foll.
} 
Then, in ancient Greece, medicine developed even more and it seems that forensic medicine was already somewhat known, as it results from Professor Mina Minovici's Complete Forensic Medicine Treatise ${ }^{2}$.

These trends were continued by other Romanian specialists, such as Andrei Ionescu in the field of dactyloscopy, Henry Stall in the field of graphology, Cantemir Rişcuţia in the field of anthropology, C. Turai in the field of trace evidence analysis, as well as other specialists who work in the Forensic Science Institute or in specialized departments of higher education institutions ${ }^{3}$.

Although, in the specialized literature ${ }^{4}$, law theoreticians and practitioners rightly assert that the Romans (considered as the initiators of legal thinking) did not use expertise as a means of evidence very often, there is, however, data which proves that the opinions of specialists with regard to the evidence were called for, in order to solve various cases, on the basis of the investigations they carried out.

Under Roman law, the known means of evidence were documents (deeds), witnesses and presumptions, then, in feudal law, a feature of the period was that the means of evidence were of a religious nature, for example: the ordeals (the red-hot iron trial by ordeal) ${ }^{5}$, the judgment of God, the imprecation.

The institution of medical forensic expertise has been known in Russia since the time of Tsar Peter I, in year 1730 a subsection of forensic and police medicine was established, and in year 1797, the general regulations on the medical forensic examination of corpses and the drafting of forensic certificates were published.

\section{REFERENCES TO THE DEVELOPMENT OF JUDICIAL EXPERTISE IN ROMANIA.}

The field of expertise has been marked by the existence of the oldest organizational structures and, given the lack of documents, it is assumed that evidence presentation in criminal matters was done by the military chief, and some tasks were performed by the medicine man or, later, by the physician.

While in the Criminal Procedure Code of 1864 the means of evidence were described sketchily, evidence and the means of evidence were extended in the Criminal Procedure Code of 1936. The old documents mainly refer to civil financial operations such as purchases and sales, donations and estate delimitations, and, in court, people relied on such documents.

The first documentary testimonies go back to the 14th century, from which time dates the existence of the High Steward, corresponding to the Interior Minister of today, who was responsible for the security of the princely court and the judgment of all cases at the Court. ${ }^{6}$

\footnotetext{
${ }^{2}$ Minovici Mina, Tratat complet de medicină legală (Complete Forensic Medicine Treatise), Vol. I, Atelierele grafice Socec (Socec Graphics Workshops), Bucharest, 1928, p. 754, Central University Library "Carol I", Bucharest, book identifier 43528.

3 Ionescu Florin, Criminalistica (Forensic Science), Editura Universitară (University Publishing House), Bucharest, 2008, p. 14.

${ }^{4}$ Cârjan Lazăr, Fundamentele criminalisticii (Fundamentals of Forensic Science), Era Publishing House, Bucharest, 2006, pp. 17-18; Pop Traian, Curs de criminologie (Criminology Course), Cluj, All Beck Publishing House, 1928, p. 254; Stancu Emilian, op.cit., p. 81.

${ }^{5}$ Cârjan Lazăr, Fundamentele criminalisticii (Fundamentals of Forensic Science), op.cit., p. 39.

${ }^{6}$ Cârjan Lazăr, Fundamentele criminalisticii (Fundamentals of Forensic Science), op.cit., pp. 38-39.
} 
Expertise dates back to a long time, the documents of old Romanian law which mention, among other things, the institution of expertise being revealing in this respect: Ipsilanti's Code, Caragea's Law (Caradja's Law), the Calimach Code.

As proof of the application of the written law, the first official expertise was carried out during the period of enforcement of the aforementioned codes, in year 1832, and it was a forensic expertise referring to a suspicious death case. From the documents of the time, it follows that in the old Romanian law, experts and their opinions had a greater power of conviction than testimonies, which fact was materialized in the stipulation that "in the situation where some experts assert something and others deny it, those who are most numerous and best-qualified shall be believed, and, if they are equal, evidence shall be resorted to".?

The beginning period was dominated by doctor Alexandru Şutzu (1837-1919), the physician of our incomparable poet Mihai Eminescu. An innovative psychiatrist, he published, in 1877, in Bucharest, a valuable monograph of forensic psychiatry - "Alienatul in faţa societăţii şi a ştiinţei" (The Mental Patient in Relation to Society and Science), a pioneering work in the field, which proposed a new attitude towards mental patients who, until then, had been kept bound in chains at monasteries in Bucharest, Iaşi and the Neamţ Monastery, proposing that they should be freed and treated scientifically by psychiatric medicine in sanatorium-type institutions. Along with his predecessor, physician George Bogdan (1859-1930), a reputed specialist, he represented with honour the school of forensic medicine of Iaşi, being the creator of new investigative techniques, author of a Collection of Forensic Medical Reports of particular interest. He published an extensive forensic medicine treatise, designed to comprise six volumes, of which only four appeared, as of year $1921^{8}$.

In the first half of the 20th century, the phrase "the Minovici Brothers" "became wellknown both in Romania and in other parts of the world as an emblem of the audacity of some pioneers who dedicated their entire lives to the grubbing of arid areas of science. Few people know, however, that they are considered to be among the founders of the new science which sprang from Forensic Medicine at the end of the 19th century, namely, forensic science".

Doctor Mina Minovici (1858-1933) ${ }^{10}$, organizer of the Romanian Forensic Medicine School, a scholar of European repute, correspondent member of the Medical Academy of Paris, was appointed in 1890 as forensic expert (physician) of Bucharest, and in 1924 he organized the "Forensic Medicine Institute" in the capital of Romania, which was among the first in the world to be founded. In 1897, he was appointed holder of the first forensic medicine specialty departments in Romania. He is the author of a "Complete Forensic Medicine Treatise" in two volumes, published in years 1928 and 1930. He had an original contribution: "sudden death", "cadaveric alkaloids", "medical anthropology", etc.

Referring to the territory of Transylvania which became complete through the 1918 Great Union act, we call forth the memory of Dr. Nicolae Minovici (1868-1941) ${ }^{11}$, Mina's

\footnotetext{
${ }^{7}$ Constantin Radu, Drăghici Pompil, Ioniţă Mircea, Expertizele, mijloc de probă în procesul penal (Expertise, as a Means of Evidence in the Criminal Trial), Editura Tehnică (Technical Publishing House), Bucharest, 2000, p. 22.

${ }^{8}$ Revista de Economie şi Administraţie Sanitară (Journal of Economics and Sanitary Administration), Issue No. 57-58 (1-2/2011) Publisher TEMCO - Tehno Electro Medical Company Cluj-Napoca, 2011, p. 9.

9 Cârjan Lazăr, Criminalistica. Tradiție și modernism (Forensic Science. Tradition and Modernism), 2009, pp. 51-53.

${ }^{10}$ Minovici Mina, op.cit. p. 754.

11 Ibid.
} 
brother. He was first a university professor in $\mathrm{Cluj}^{12}$ in 1919, then in Bucharest, where he established as first institution "Salvarea" (Emergency Rescue Service) and the "Emergency Hospital". He made valuable contributions in the fields of "congenital heart abnormalities", "forensic osteology", "the mechanisms of death by hanging", etc. His post-mortem photography system was awarded the gold medal at the International Social Hygiene Exhibition, held in Rome, in 1912. Then, the field of forensic medicine in Cluj also began with Nicolae Minovici, after 1918, followed by Mihail Kernbach (who would publish, in 1924, Tehnica autopsiei medico-legale (Forensic Autopsy Technique) ${ }^{13}$.

\section{ON MILITARY JUSTICE ${ }^{14}$}

The Ministry of War, in the official edition of the Military Justice Code, published in 1917, gives us some insights into the establishment of military justice and the amendments made to the Military Justice Code. The Romanian Military Justice Code, in force as of $5^{\text {th }}$ of April 1873, was borrowed from the French, by translating the French Military Justice Code of 1857.

Military justice, as a special court, has been known in all organized states since the times of the Romans. On our territory, before the French code was translated, Alexandru Ioan Cuza had issued a decree on $6^{\text {th }}$ of July 1859 , by virtue of which the Romanian military justice was to operate.

The Romanian Military Justice Code of 1873 was remade in 1881, undergoing subsequently, in year 1884, alterations of some of its Articles. Thus, through the law of $25^{\text {th }}$ of March 1881, an additional Title II was established, on the basis of which were created, as attached to all regiments, the Disciplinary Boards, military courts of first instance, with their competence limited to certain deeds, and concerning only lower-ranking military personnel. In year 1905, through the law of $12^{\text {th }}$ of April, Disciplinary Boards were also set up as attached to hunter battalions, as well as to the military navy, so that, on $3^{\text {rd }}$ of March 1906, more Articles of the Code could be altered.

On $21^{\text {st }}$ of December 1910, an Additional Title 2 was established, which completely altered the military warfare legislation, by creating the Martial Courts, increasing the competence of military criminal courts, and vesting the Great Commandments with legislative power prerogatives. On $15^{\text {th }}$ March 1917, more changes were made to the Additional Title 2.

At the end of the military hostilities caused by the First World War, through the transition of the army to a state of peace in April 1921, the enforcement of the Additional Title 2 and of the entire legislation of the period 1910 to 1917 being abolished, there was a return to the application of military justice as established by the old Code, with the amendments made in year 1900, so that all the Articles of the old Military Justice Code which had governed military justice in terms of peacetime organization, jurisdiction and procedure prior to 1910, became applicable in the united national territory after the completion of the 1918 Union act.

\footnotetext{
${ }^{12} \mathrm{http}: / /$ rmj.com.ro/articles/2012.4/RMR Nr-4 2012 Art-15.pdf, accessed on $10^{\text {th }}$ of October 2018.

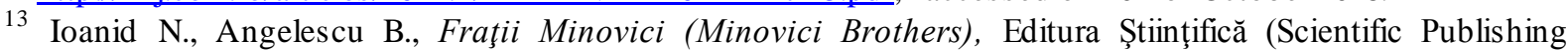
House), Bucharest, 1970.

${ }^{14}$ Chiru D. Vasile, Dreptul penal militar, infracțiunile (Military Criminal Law, Criminal Offences), Ancora Publishing House, Bucharest, 1924, pp. 5-6.
} 


\section{CONCLUSION}

Medical doctors and officers specializing in the line of police investigation have played an important role in the evolution of forensic science as a science of finding the truth.

\section{BIBLIOGRAPHY:}

Mihuleac Emil, Expertiza judiciară (Judicial Expertise), Editura Ştiinţifică (Scientific Publishing House), Bucharest, 1971;

Minovici Mina, Tratat complet de medicină legală (Complete Forensic Medicine Treatise), Vol. I, Atelierele grafice Socec (Socec Graphics Workshops), Bucharest, 1928, p. 754, Biblioteca Centrală Universitară „Carol I” (Central University Library “Carol I”), Bucharest, book identifier 43528;

Ionescu Florin, Criminalistica (Forensic Science), Editura Universitară (University Publishing House), Bucharest, 2008;

Cârjan Lazăr, Fundamentele criminalisticii (Fundamentals of Forensic Science), Era Publishing House, Bucharest, 2006;

Pop Traian, Curs de criminologie (Criminology Course), Cluj, All Beck Publishing House, 1928;

Constantin Radu, Drăghici Pompil, Ioniţă Mircea, Expertizele, mijloc de probă în procesul penal (Expertise, as a Means of Evidence in the Criminal Trial), Editura Tehnică (Technical Publishing House), Bucharest, 2000;

Revista de Economie şi Administraţie Sanitară (Journal of Economics and Sanitary Administration), Issue No. 57-58 (1-2/2011), Publisher TEMCO - Tehno Electro Medical Company Cluj-Napoca, 2011;

Cârjan Lazăr, Criminalistica. Tradiție și modernism (Forensic Science. Tradition and Modernism), 2009;

Ioanid N., Angelescu B., Fraţii Minovici (Minovici Brothers), Editura Ştiințifică (Scientific Publishing House), Bucharest1970;

Chiru D. Vasile, Dreptul penal militar, infracțiunile (Military Criminal Law, Criminal Offences), Ancora Publishing House, Bucharest, 1924. 